\title{
Tax Evasion Causes and Prevenience or Rebutment Way of Tax Dodger Phenomenon
}

\author{
Corina Nichitcin, Alecu Russo Balti State University, Republic of Moldova
}

\begin{abstract}
Tax evasion phenomenon, having negative impact on many levels, must be constantly pursued in order to minimize tax circumvention and control section in the issue of tax fraud. From international theory and experience it is known that normal functioning of market economy is conditioned by promotion of certain efficient policies and adequate legislation implementation. So, as Republic of Moldova is no exception among countries where tax evasion is, the study of this subject is up-to-date and it is required for presenting these problems at national and international levels.
\end{abstract}

\section{Keywords}

Tax evasion, tax elusion, tax fraud, tax facilitations, taxes, assessments, fiscal control, legislation, education tax, liability, revenue authority

JEL Code: $H 26$

\section{Tax Evasion Theoretical Concepts}

Tax evasion is a complex phenomenon that manifests as a taxpayer reply at its constraint action imposed by the state and it has economic, social, political, moral, general or specific causes which are rooted in the characteristics of the analyzed period.

Human nature has always tended to place firstly public interest then the private one. It is rather inclined to consider tax evasion as a prejudice than a legitimate contribution to public expenditure and to envisage worse that who wants to reduce patrimony.

Collation of these interests increases the appearance of a new reality that of persons' avoidance from participating in state revenues formation.

Therefore, tax evasion inheres avoidance phenomenon by all means, integral or partial honouring of taxes, assessments, contributions and other liabilities of natural and legal persons resident and no resident, towards state budget, local budgets.

It is true that the term acquired this significance during last decades, but at its entry, particularly in inter-war period, tax evasion was used in a restrict acceptance being identified with tax fraud.

In this context, it is remarkable tax evasion type's determination in relation to laws in force. We distinguish tax evasion or so-called in treatises tax elusion, and illegal tax evasion considered tax fraud.

Tax evasion phenomenon is presented schematically in the figure below: 


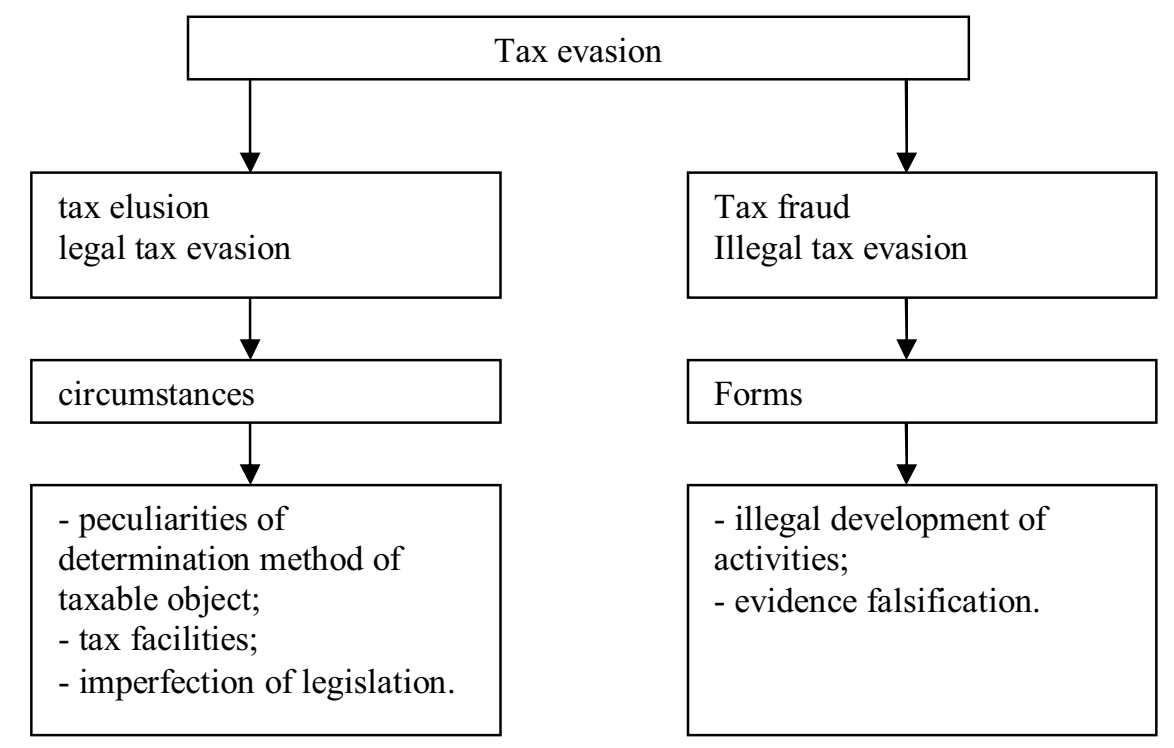

Figure. 1. Tax evasion

Source: G. Ulian, O. Cuzmina (2007) Administrare fiscală. Curs de lecții, CEP USM, Chişinău, p. 49

From those presented in the figure above, it is noticeable that tax elusion represents integral or partial taxes non-payment without qualifying it as a contravention or infraction while tax fraud means taxes non-payment by laws in force contravention.

\section{Tax Evasion Causes}

Tax evasion phenomenon has a negative impact from different perspectives. Tax nonpayment is a serious state problem in West. Firstly, state programs financing is reduced because of insufficient budget resources. Secondly, those who do not pay taxes are in a more favourable situation to the honest payers in terms of market competition. It determines tax evasion of the other subject of economical activity. Thirdly, in terms of tax contravention spread that causes part of the budget revenue deficit, the state may offset these resources by introducing new assessments and tax raises that condition chain reaction.

The main tax evasion causes may be the following:

- Tax payer reaction to fiscal burden;

- Imperfection of fiscal control department;

- Comparison of tax payment and non-payment consequences;

- Unawareness and ignorance of tax law;

- The erroneous interpretation and application, even abusive of tax laws;

- Inobservance by economic agents of regulations concerning evidence organization of patrimony, incomings, expenditures and financial results. Prevailingly, there are situations when accounting is entrusted to lays, to people without necessary training and experience or to those who did not assimilate new regulations;

- Illegal work interpreted as forms of activity on one's own account, without authorization and so-called hack work which due to its hidden character, balks of fiscal control. These activities occur oftener in trade and agriculture;

- The imperfection of tax laws;

- Insufficient collaboration of the control apparatus with the other state institutions; 
- The existence of non-advanced control structures deprived of the tax evasion fight ability practiced in different ways;

- Insufficient stimulation of the tax control apparatus, non-correlation of the salary level to social work importance;

- An inland revenue relatively raised to common taxpayer possibilities;

- The insufficiency of tax and civil education.

In these circumstances it is worth mentioning that the reduced level of tax liability allowance generates a repulsive taxpayer attitude and it tends to avoid, to ignore, to decry tax laws and to practice tax evasion on the various ways and means.

\section{The Result of Fiscal Control in the Republic of Moldova}

Taking into account that "the probability of achieving an event is the ratio between the number of positive cases and the number of possible cases" and analyzing the data of the State Tax Service, probability calculations of tax evasion detection in 2008 in the Republic of Moldova is $50.36 \%$. The detection probability registers different values depending on the type of controls carried out.

Table 1. Analysis of Tax Controls Carried Out in 2008

\begin{tabular}{|c|c|c|c|c|c|c|}
\hline \multirow[t]{2}{*}{ Name index } & \multicolumn{2}{|c|}{$\begin{array}{ll}\begin{array}{l}\text { Fiscal } \\
\text { (units) }\end{array} & \text { control } \\
\end{array}$} & \multirow[b]{2}{*}{ 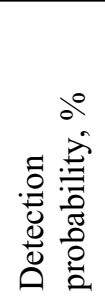 } & \multicolumn{2}{|c|}{$\begin{array}{l}\text { excises, taxes (thousand } \\
\text { lei) }\end{array}$} & \multirow{2}{*}{$\begin{array}{l}\text { Applied } \\
\text { fiscal } \\
\text { sanctions } \\
\text { (thousand } \\
\text { lei) }\end{array}$} \\
\hline & 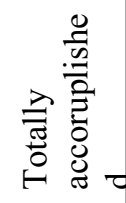 & 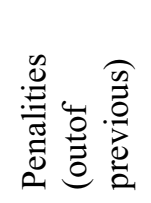 & & 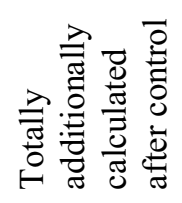 & 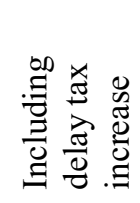 & \\
\hline $\begin{array}{l}\text { Spot Fiscal } \\
\text { controls } \\
\text { verification } \\
\text { method } \\
\text { inclusively } \\
\end{array}$ & 49023 & 24689 & 50,36 & 106367.3 & 15043.3 & 94728.3 \\
\hline Total & 5323 & 4099 & 77,01 & 55454.3 & 8271.5 & 41512.9 \\
\hline $\begin{array}{l}\text { Economic agents } \\
\text { exclusion } \\
\text { inclusively }\end{array}$ & 914 & 362 & 39,61 & 244.8 & 56.2 & 209.7 \\
\hline Thematic & 12758 & 6645 & 52,1 & 47516,8 & 6300,6 & 25243,9 \\
\hline Repeated & 38 & 30 & 78,95 & 277,5 & 49,2 & 814,7 \\
\hline Active & 17478 & 8189 & 46,85 & 18,1 & 1,2 & 21333,7 \\
\hline By opposition & 2505 & 150 & 5,99 & 781,2 & 129,6 & 831,8 \\
\hline $\begin{array}{l}\text { By chamber } \\
\text { checking }\end{array}$ & 9119 & 4847 & 53,15 & 1646,1 & 209,4 & 4231,4 \\
\hline Other types & 1802 & 729 & 40,46 & 673,0 & 81,5 & 760,4 \\
\hline
\end{tabular}

(Source: State Tax Service Report, 2008)

After tax control accomplished in 2008 sanctions of 94728.3 thousands lei were inflicted. Therefore, cases of tax contraventions were registered. The adopted decisions improve continuously and the national public budget revenues increase.

\section{Measures of Tax Evasion Prevention and Rebutment}


Authority's attitude has an important role in the process of taking taxpayer's decision refusing the submission to the legal norms looking for legal possibilities of paid taxes diminution or choosing the "escape option" in "underlying economy'. The efficiency of rebutment measures of "underlying economy" is determined decisively by the economical situation and its development perspectives. For a certain taxpayer the escape from the abovementioned sector is connected with great expenditure, moreover, once paying the assessments according to legal norms, he "comes to light", but his business partners are also observed.

Analyzing this problem, we may state that in countries with transition economy, fiscal systems which function do not always assure the incoming revenues from local budgets of those regions where economical activity actually occurs. That's why the idea concerning the determination of tax payment arrangement by the enterprises subsidiary and the change of taxpayer address according to the place of production sector and actions.

A well-defined notion of benevolence and of a religious activity organization for taxing is necessary to be planned at a legal level. It is required to forbid individual tax facilities for increasing the tax system neutrality. The enlargement of the preventive tax control field constitutes a main condition for reducing the number of tax contravention. The preventive complex of measures offers consulting and methodical help to taxpayers, the publication of tax legislation modifications, the publication of articles referring to tipical and special contraventions of tax legislation, as well as the information about the legal arbitration practice in this field. It is also required to use control by making a poll and transferring the permanent control on the second plan. Besides, there are other methods of tax contraventions rebutment which are worth mentioning:

- The assignation of a proportion that tends to an optimization between salaries and stimulants for fiscal apparatus financial incentive;

- The development of staff training system referring to the tax evasion prevention, identification and rebutment;

- The improvement of services for taxpayers by offering tax assistance;

- The identification of all taxpayers who fall under tax laws incidence;

- The correct and complete identification of taxable things;

- The confiscation of the assets or of the undeclared valuable goods etc.

The diminution of tax evasion phenomenon to the level that keeps it under control is a complex process which supposes disciplinary approach and the implementation of legislative, organizational, social and psychological measures that may assure the improvement of the business milieu and to contribute to the raising of volunteer conformation level in the process of liabilities payment to the general consolidated budget. In this context, it is important the taxpayers instruction by introducing fiscal training lessons that would give basic knowledge about the tax role and contraventions at which are submitted in case of tax non-payment or abstraction. Therefore, the international tax practice concludes that a modern tax system should also inform and teach taxpayers about their liabilities in tax declarations elaboration, keep right note of revenues and expenditure from the activity nature, penalties and sanctions which are implemented to those who break the laws.

Finally, we may conclude that tax evasion is the logic issue of an imperfect legislation for which rebutment it is not required to establish some drastic sanctions, but it should be effectuated an efficient and strict tax control. A viable legislative system and, first of all, a fiscal education of citizens should be implemented.

\section{Bibliography}

1. Agafița, C. (2008) Particularitățile evaziunii fiscale în economiile de tranziție. In: Revista economică Sibiu - Chişinău, vol. I 
2. Iachim I., Darie, V. (2008) Impactul evaziunii asupra mediului concurențial şi a celui investițional. In: Revista economică Sibiu - Chişinău, vol. II

3. Popescu, L., Pîrlici, V., Popescu,C. (2007) Fiscalitate şi drept financiar şi fiscal, Ed, SITECH, Craiova

4. Stratulat, O. (2004) Impozite. Abordare teoretică, Evrica, Chişinău

5. Ulian, G., Cuzmina, O. (2007) Administrare fiscală. Curs de lecții, CEP USM Chișinău

6. Raportul privind activitatea Serviciului Fiscal de Stat pentru anul 2008

7. www.fisc.md 